African Crop Science Journal by African Crop Science Society is licensed under a Creative Commons Attribution 3.0 Uganda License. Based on a work at www.ajol.info/ and www.bioline.org.br/cs DOI: https://dx.doi.org/10.4314/acsj.v28i1.17S

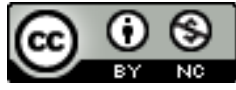

\title{
EFFECT OF AGRIBUSINESS SUPPORT SERVICES ON CHOICE OF DAIRY COOPERATIVE MARKET CHANNELS IN KENYA
}

\author{
D. OKELLO, G. OWUOR, C. LAROCHELLE ${ }^{1}$ and E. GATHUNGU
}

\author{
Department of Agricultural Economics and Agribusiness Management, Egerton University, \\ P. O. Box 536, Njoro, Kenya \\ ${ }^{1}$ Virginia Tech, Blacksburg, VA 24061, USA \\ Corresponding author: dckokello@gmail.com
}

\begin{abstract}
Kenya is witnessing an immense increase in number of smallholder dairy agripreneurs sourcing income from the dairy sub-sector. Smallholder dairy agripreneurs who dominate the production sector are forced to sell milk to informal buyers such as middlemen/women, who exploit them by paying less than the market price. As a result of this, the Kenyan Government has made significant efforts to upgrade dairy cooperatives to link the dairy agripreneurs with consumers. In spite of this, milk marketing is still dominated by traditional informal outlets. This study sought to determine the effect of provision of agribusiness support services on choice of dairy cooperative market channel. Data were collected from a cross-sectional survey of 682 respondents from Muranga County in Kenya, using a semistructured questionnaire. Results revealed that provision of business plan training, group marketing, pregnancy diagnosis and deworming support services had significant and positive effects on the choice of cooperative market channel. In contrast, access to vaccination services and supply of feeds had negative effectson the choice of cooperative market channel. This study recommends strong coordination among the agribusiness support service providers and the dairy cooperatives in order to increase adoption of the cooperative marketing channel. In addition, dairy cooperatives need to redesign their business models to ensure that their members not only receive agribusiness support services, but also get better prices and prompt payments to increase supply of milk to cooperatives by dairy agripreneurs.
\end{abstract}

Key Words: Agribusiness support, cooperatives, dairy agripreneurs

\section{RÉSUMÉ}

En ces deux dernières décennies, le secteur laitier au Kenya a attiré l'attention d'un grand nombre des petits entrepreneurs, qui en outre considèrent l'activité entrepreneuriale dans le secteur laitier comme leur source principale de revenu. Mais au vu de leur taille d'activités, ils sont contraints d'opérer dans le circuit informel de commercialisation de leurs produits laitiers, et par conséquent perçoivent le prix de revient inferieur, que celui du marché formel. Par contre le Gouvernement Kenyan avait mis en place une série des politiques de soutien aux coopératives laitières du pays afin de formaliser le circuit de 
commercialisation des produits laitiers, pour une connectivité efficace entre les petits entrepreneurs du secteur laitier à leurs consommateurs potentiels. Malgré ces efforts, il est à signaler que le marché laitier kenyan est toujours dominé par un circuit de commercialisation informelle. Cette étude cherchait à déterminer les effets des subventions de soutien aux entreprises laitières sur les choix du circuit de commercialisation. Les données étaient collectées sur un échantillon de 682 répondants dans la collectivité de Muranga au Kenya, sur base d'une enquête transversale, utilisant un questionnaire semi-structuré. Les résultats ont révélé que la formation à la gestion d'affaires, le groupement des vendeurs, le diagnostic de grossesse et l'accès aux services de déparasitage ont eu des effets significatifs et positifs sur le choix du circuit de commercialisation par coopérative. En revanche, l'accès aux services de vaccination et la fourniture d'aliments ont négativement influencé le choix du circuit de commercialisation par coopérative. Ainsi, la présente étude recommande une effective coordination entre les prestataires de services de soutien à l'agro-industrie laitière et les coopératives afin d'accroître l'adoption du circuit de commercialisation formel par coopérative. En outre, les coopératives laitières doivent réviser leurs modèles d'opération d'achat et de vente pour garantir à leurs membres non seulement des services de soutien, mais également les meilleur conditions de paiement, à des prix rémunérateur, à temps pour enfin financer les approvisionnements en lait et accroitre ainsi l'offre de lait de la part des Agripreneurs.

Mots Clés: Subvention Agrobusiness, coopératives, Agripreneurs laitiers

\section{INTRODUCTION}

Dairy farming plays an important role in providing nutrition and source of livelihood to majority of Kenyans. About 1.8 million agripreneurs are involved in dairy farming, with $80 \%$ of them being smallholders, with farm sizes of 1.21-2.02 hectares (Kilelu et al., 2018). According to FAOSTAT (2018), the Kenyan dairy sector produced 4 billion litres of milk in 2018, which placed it among the highest producers and consumer of milk in Africa.

Due to lack of efficient marketing systems, $86 \%$ of milk produced in Kenya is sold through the informal marketing channels; and the rest to dairy processing companies, through farmer organisations (Mwambi et al., 2018). This depicts the important role played by informal markets that includes middlemen/women and retailers, in ensuring that milk reaches the final consumer. However, these informal buyers often exploit smallholder dairy agripreneurs, by paying less than the market price (Singh, 2018).

To address these challenges, cooperative marketing has emerged as an alternative marketing channel for milk distribution in Kenya. Cooperatives are involved in collection and bulking, cooling and coordinating the sale of raw milk. In addition, some cooperatives offer agribusiness support services, such as supply of feeds, provision of artificial insemination (AI) and veterinary services, credit and training (Van der Lee et al., 2018). Moreover, some are involved in processing of milk into products such as pasteurised milk, yoghurt, ice-cream and fermented milk (Ngeno, 2018). Through cooperatives, smallholder agripreneurs can potentially overcome constraints related to market inefficiencies, access to financial as well as inputs and output markets, which impede smallholder agripreneurs' access to lucrative markets (Burke et al., 2015; Royer et al., 2016; Lutz and Tadesse, 2017). This is because collective action empowers dairy agripreneurs to have more bargaining power and become more competitive (Kumar et al., 2018).

Dairy agripreneurs in Kenya receive support services from a variety of organisations, which include public, private and Non-Governmental Organisations (NGOs). According to Oloo 
(2016), these relate to production, group marketing, financial and business planning support services. Production support services are livestock services related to supply of feeds and animal health services, which are divided into curative and preventive services (Van der Lee et al., 2018). Curative services are related to clinical care for the animals; while preventive services include vaccination, diseases control and vector control.

Most of these services are provided by dairy cooperatives in order to motivate agripreneurs to supply milk to the cooperatives (Bardhan et al.,2015; WortmannKolund•ija, 2019). In the past decade, efforts have been made by governmental and nongovernmental organisations to improve provision of dairy inputs and support services in dairy cooperatives, in order to alleviate the constraints facing smallholder dairy agripreneurs. However, there exists a knowledge gap of the impact of these agribusiness support services on choice of dairy cooperative market channels. This study, therefore, aimed at determining the overall effect of agribusiness support services on the choice of dairy cooperative market channels among dairy agripreneurs in Kenya.

\section{MATERIALS AND METHODS}

This study was conducted in Murang'a County in central Kenya; which lies between longitudes $36^{\circ}$ East and $37^{\circ} 27^{\prime}$ East and latitudes of $0^{\circ}$ $34^{\prime}$ 'South and $1^{\circ} 7^{\prime}$ 'South of the equator. This is at an altitude range of about $914 \mathrm{~m}$ above sea level (asl) in the East to 3,353 $\mathrm{m}$ asl along the slopes of the Aberdare ranges in the West. The County is heavily involved in mixed farming, with an average household farm size of 0.57 hectares. Dairy cattle are the dominant livestock species in the area. The County represents a vibrant dairy sector with the county government initiating several interventions related to agribusiness support services (Murang'a CIDP, 2018).
This study used both quantitative and qualitative approaches through a crosssectional survey. This allowed the establishment of facts in relation to access to agribusiness support services and its influence on choice of markets. Prior to data collection, a research permit was secured from the National Commission for Science Technology and Innovation (NACOSTI), which is the legal body responsible for regulating research activities in Kenya. Once the permit was approved, we then sought approval from County Government of Murang'a Ministry of Agriculture, Livestock and Fisheries for final approval and release of information by the respective Sub-County officers.

A multi stage sampling procedure was used to obtain respondents for the study. Within Murang'a county, four sub-counties, Gatanga, Maragwa, Kiharu and Kandara were purposively selected based on the presence of dairy cooperatives initiated by the county government, agripreneurs and nongovernmental promoters. In addition, these sub-counties had milk collection centres whose objective was to link agripreneurs to the market and to offer agribusiness support services. Within the four sub-counties, three wards were randomly selected to give a total of twelve wards. Then, a proportional sampling technique was employed to select the number of households that participated in the study. The sample size of 682 respondents was determined using Cochran (1963) formula.

The respondents were briefed about the purpose of the study, and thereafter requested for an informed consent to participate in the study. Upon consent by the selected agripreneurs, data were collected through interviews using semi-structured questionnaires. The interview sessions took an average of 90 minutes per household.

This study employed Multinomial logit model (MLM) to determine influence of agribusiness support services on choice of dairy cooperative market channel. The 
dependent variables were milk market channels, which included cooperative, middlemen/women, retailers and consumers. Multinomial logit model was used because these market choices were categorical and dairy agripreneurs were required to choose one main market channel to which they sold their milk. Singh (2018) asserts that multinomial logit model is used when the dependent variable is categorical, representing more than two categories and each category is compared with the reference category.

In this study the reference marketing channel was cooperative and it was compared with middlemen/women, retailers and direct to consumers. The independent variables were agribusiness support services, which included financial, business training, group marketing, curative treatment services, artificial insemination services, pregnancy diagnosis services, deworming services, vaccination services and supply of feeds. The multinomial logistic regression for the choice of milk market channels is summarised in Equation 1.

$P(Y i=j)=e^{\beta^{\prime}} j X_{i} / \sum_{k=0}^{2} e^{\beta^{\prime}} k X_{i} j=0,1,2$

Equation 1

Where:

$\mathrm{Yi}=$ the probability of household participation in the milk market channel;

$\mathrm{j}=$ the indicator variable of market channel $(0=$ cooperative, $1=$ middlemen/women, $2=$ retailers and $3=$ direct to consumer);

$X_{i}=$ the vector of explanatory variables; and $\beta s$ are the regression coefficients estimated by the maximum likelihood method.

The base category comprised of the households who sold milk to cooperatives. To interpret the coefficients in multinomial logit regression, marginal effects of the explanatory variables were conducted as follows:

$$
\delta p(Y) / \delta X_{i}=\beta X_{i}^{*} \exp [\mathrm{z}] /[1+\exp (\mathrm{z})]^{2}
$$

Equation 2

Where:

$\mathrm{z}=$ the sum of coefficients multiplied by the means of the respective variables plus the constant term.

Equation 2 provides an estimate $\beta$ s of the effect of the determinants Xi on the market channel $\mathrm{Y}$.

A positive coefficient on the explanatory variables indicates a positive influence on the dependent variable; while a negative coefficient indicates a negative influence on the dependent variable, which is choice of market channels. The quantitative data collected on dairy agripreneurs access to financial, business training, group marketing, curative treatment services, artificial insemination services, pregnancy diagnosis services, deworming services, vaccination services, supply of feeds and choice of marketing channels were analysed using STATA version 15.

\section{RESULTS AND DISCUSSION}

Access to agribusiness support services. Table 1 presents dairy agripreneurs access to agribusiness support services. A total of $95.2 \%$ of the respondents had access to production support services, $56.1 \%$ to financial support, $47.2 \%$ to group marketing support and only $39.6 \%$ of the respondents had access to business plan training support services. These results imply that majority of dairy agripreneurs respondents were keen on getting production support services, which included mainly curative treatment, artificial insemination, pregnancy diagnosis, deworming, vaccination and supply of feeds. The plausible explanation is that many dairy agripreneurs did not view dairying as a business that required business support. Instead, they could have known it as production oriented, thereby focusing on 
TABLE 1. Type of agribusiness support services accessed by dairy agripreneurs in central Kenya

\begin{tabular}{lcr}
\hline Type of support service & \multicolumn{2}{c}{ Access to agribusiness support services } \\
\hline & Yes & No \\
Production support & $649(95.2 \%)$ & $33(4.8 \%)$ \\
Financial support & $382(56.1 \%)$ & $300(43.9 \%)$ \\
Business plan training support & $270(39.6 \%)$ & $412(60.4 \%$ \\
Group marketing support & $322(47.2 \%)$ & $360(52.8 \%)$
\end{tabular}

increasing their access to production support services.

Moreover, majority of service providers were reportedly mostly restricted to provision of production support services, rather than other important dairy services such as business plan training and financial services. Therefore, in many cases, the transitioning to seeking financial and business support was almost by default rather than through their willingness. Overall, the market orientation of many dairy agripreneurs is still subsistence with few transiting into commercial farming. They considered getting production support before focusing on other support services. This scenario is linked to the emergence of dairy cooperatives, which offered production support services to smallholder dairy agripreneurs, as way of improving their productivity and linking them to markets. This finding is similar to that Omondi et al. (2017), who reported that dairy agripreneurs in Kenya had high demand for production support services, which were supplied by dairy cooperatives.

Table 2 presents the different types of production support services utilised by the dairy agripreneurs in central Kenya. Among these services, access to artificial insemination and deworming services recorded the highest demand of respondents utilising them (25.9 and $23.2 \%$, respectively). This implies that for most dairy agripreneurs, the performance of cattle in terms of improved productivity and reduced mortality of the calves held high priority positions. The greater preference for artificial insemination and deworming support services by dairy agripreneurs, was probably because they act as preventive measures and yet improve their milk production. Kumar (2018) contends that cooperative market channels play a crucial role in enhancing smallholder (agripreneurs) access to production support services, including supply of inputs and animal health services, which are crucial to enhancing cattle productivity and farm income.

The types of production service providers and types of services received by smallholder dairy agripreneurs in central Kenya are presented in Table 3. Majority of the respondents $(84.4 \%)$ received supply of feeds support services from private veterinary clinics, which conforms to the finding of Bardhan et al. (2015) that majority of dairy agripreneurs in India received feed supply from private practitioners. In addition, 69.6 and $62.2 \%$ of the dairy agripreneurs were receiving artificial insemination and deworming services from private practitioners. The plausible explanation is that most of insemination and deworming services offered by public sources have high non-conception rate and service provider non-responsiveness due to limited staffing in public veterinary clinics. Due to lack of these services in the public veterinary clinics, agripreneurs opted to seek support services from private practitioners (Omondi et al.,2017). Dairy cooperatives need to ensure that they supply, their members with responsive artificial and 
TABLE 2. Types of production support services utilised by smallholder diary agripreneurs in central Kenya

\begin{tabular}{lcc}
\hline Types of production support services & Frequency & Percentage \\
\hline Curative treatment services & 330 & 16.3 \\
Artificial insemination services & 526 & 25.9 \\
Pregnancy diagnosis services & 43 & 2.1 \\
Deworming services & 470 & 23.2 \\
Vaccination services & 330 & 16.3 \\
Supply of feeds services & 329 & 16.2 \\
\hline
\end{tabular}

TABLE 3. Production service providers and types of services received by dairy agripreneurs

\begin{tabular}{lcccc}
\hline Types of production service & \multicolumn{4}{c}{ Type of production service providers (\%) } \\
\cline { 2 - 5 } & $\begin{array}{c}\text { Private vet } \\
\text { clinic }\end{array}$ & $\begin{array}{c}\text { District vet } \\
\text { clinic }\end{array}$ & NGO/project & Other, specify \\
\hline Curative treatment services & 42.4 & 8.5 & 0.0 & 0.0 \\
Artificial insemination services & 69.6 & 11.2 & 0.2 & 0.0 \\
Pregnancy diagnosis services & 5.9 & 0.8 & 0.0 & 0.0 \\
Deworming services & 62.2 & 9.9 & 0.2 & 0.2 \\
Vaccination services & 42.1 & 8.6 & 0.2 & 0.0 \\
Supply of feeds services & 84.4 & 15.3 & 0.2 & 0.2 \\
\hline
\end{tabular}

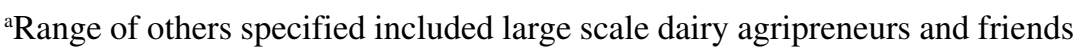

deworming services and proper staffing who would timely reach out to dairy agripreneurs.

Choice of milk market. Multinomial logit regression model outputs with the corresponding marginal effects are presented in Table 4; with the base category which was cooperative market. The estimated coefficients differed significantly across the different milk marketing outlets. Access to training in business planning had a significant and positive effect on the choice of cooperative marketing channels. In fact, training in business planning considerably reduced the probability that a dairy agripreneur would sell to middlemen/ women, retailers and to consumers, relative to cooperatives, by $7.5,11.7$ and $5.6 \%$, respectively.
A plausible explanation is that access to business planning training tended to increase access to the relevant production and market information (Oleksiy et al., 2013). Through business plan training, agripreneurs are empowered with knowledge in farm planning, record keeping, market information and financial management (Wongtschowski et al., 2013). This, in turn, increases agripreneurs ability to be more market oriented and to seek new opportunities and stable marketing channels, such as cooperatives. Our finding is in contrary to that of Kumar et al. (2019), who observed that agripreneurs with agriculture training background were more likely to sell to multiple markets to diversify their risk and increase their incomes, compared to those who did not have training. However, 
TABLE 4. Multinomial logit regression modeloutputs for the effect of agribusiness support services on choice of milk market channel in central Kenya

\begin{tabular}{|c|c|c|c|c|c|c|c|c|c|c|}
\hline \multirow[t]{3}{*}{ Independent variables } & \multicolumn{10}{|c|}{ Estimate coefficients (Base outcome $=$ Cooperative) } \\
\hline & \multicolumn{2}{|c|}{ Middlemen/women } & \multicolumn{2}{|c|}{ Retailers } & \multicolumn{2}{|c|}{ Consumers } & \multicolumn{4}{|c|}{ Marginal effects } \\
\hline & Coefficient & SE & Coefficient & SE & Coefficient & SE & $\begin{array}{l}\text { Middle } \\
\text { men/ } \\
\text { women }\end{array}$ & Retailers & Consumers & Cooperatives \\
\hline Access to credit & 0.1044 & 0.4847 & 0.4811 & 0.5096 & 0.2463 & 0.5456 & 0.0041 & 0.0364 & 0.0113 & -0.0518 \\
\hline Receive business plan training & $-0.9970 * *$ & 0.5026 & $-1.7477 * * *$ & 0.5674 & $-1.2859 * *$ & 0.6087 & -0.0754 & -0.1165 & -0.0564 & 0.2483 \\
\hline Group marketing support services & s $-8.5474 * * *$ & 1.1056 & $-6.5312 * * *$ & 0.8335 & $-6.7128 * * *$ & 1.0929 & -0.6336 & -0.1672 & -0.1329 & 0.9338 \\
\hline Curative services & -0.5194 & 0.4837 & -0.6948 & 0.5067 & -0.5874 & 0.5393 & -0.0443 & -0.0481 & -0.0276 & 0.1200 \\
\hline AI services & -0.4236 & 0.6203 & -0.6493 & 0.6474 & -0.2687 & 0.6930 & -0.0382 & -0.0537 & -0.0083 & 0.1002 \\
\hline Pregnancy diagnosis services & -1.2579 & 0.7956 & $-2.8411 * *$ & 1.2662 & -0.5086 & 0.9073 & -0.0846 & -0.0983 & -0.0150 & 0.1979 \\
\hline Deworming services & $-1.0046^{*}$ & 0.5873 & 0.8778 & 0.6577 & $-1.1022^{*}$ & 0.6336 & -0.1251 & 0.0775 & -0.0750 & 0.1226 \\
\hline Vaccination services & -0.3249 & 0.4756 & $0.8524 *$ & 0.5075 & -0.3957 & 0.5340 & -0.0424 & 0.0773 & -0.0268 & -0.0081 \\
\hline Supply of feeds & $2.1970 * * *$ & 0.5779 & $1.0161 *$ & 0.5955 & 0.9525 & 0.6492 & 0.2291 & 0.0478 & 0.0306 & -0.3075 \\
\hline \multirow[t]{5}{*}{ Constant } & $3.2360 * * *$ & 0.8455 & 1.0370 & 0.9187 & $2.3282 * * *$ & 0.9262 & & & & \\
\hline & Model fit & & & & & & & & & \\
\hline & $\log$ & - & $\mathrm{LR} \operatorname{chi}^{2}(27)$ & 807.62 & & & & & & \\
\hline & likelihood & 350.96 & & & & & & & & \\
\hline & Prob $>$ chi 2 & 0.0000 & Pseudo R2 & 0.5350 & & & & & & \\
\hline
\end{tabular}

Robust standard errors in parentheses $* * * \mathrm{P}$-value $<0.01, * * \mathrm{P}$-value $<0.05, * \mathrm{P}$-value $<0.1$ 
in our scenario, dairy agripreneurs who had received training in business planning preferred the cooperative channel due to its ability to give stable prices and market. This is, considering the fact that the dairy sector in Kenya is faced with milk prices fluctuations which affects financial performance of smallholder dairy agripreneurs (Oloo, 2016). This finding illustrate that if cooperatives are able to offer business plan training to dairy agripreneurs, this would motivate the agripreneurs to sell milk to dairy cooperatives.

Access to group marketing support services had a negative effect on the dairy agripreneurs' decision to choose middlemen/ women, retailers and consumers in comparison with cooperatives (Table 4). The finding suggests that access to group marketing decreased the probability of selling milk to middlemen/women, retailers and consumers by $63.4,16.7$ and $13.3 \%$, respectively. Agripreneurs accessing group support services opted to sell milk to cooperatives probably because of their stable markets and guaranteed sales. This most likely increased their incomes through greater bargaining power, which in turn probably increased the price of milk. This finding is similar to that of Chagwiza et al. (2016), who found that cooperatives improved collective action among dairy agripreneurs and enabled them to access more secure markets and better prices for milk, and more affordable dairy inputs.

Access to cattle pregnancy diagnosis support services had a significant negative effect $(\mathrm{P}<0.05)$ on the choice of retail marketing outlet (Table 4). Based on marginal effects, an increase in access to pregnancy diagnosis services reduced the likelihood of dairy agripreneurs selling milk to retailers by $9.8 \%$, compared to the case of cooperatives. This may be attributed to the fact that most dairy cooperatives educate and offer their members this support service, by looking for veterinarian and negotiating for the members on the price of service. Pregnancy diagnosis is very vital in monitoring dairy cows' reproductive performance; however, it is costly for majority of smallholder farmers. Therefore, agripreneurs opt for cooperatives since they avail pregnancy diagnosis services to its members (Kumar et al., 2018). This reaffirms the need for dairy cooperatives to have the capacity to deliver this support service which could increase agripreneurs selling their milk through cooperatives.

Access to deworming support services also had a weakly significant $(\mathrm{P}<1 \%)$, yet negative influence on the choice of middlemen/women and consumers as markets for milk (Table 4). An increase in deworming support services lowered the likelihood of the agripreneurs selling to middlemen/women and consumers by 12.5 and $7.5 \%$, respectively. A plausible explanation is that increase in deworming support services acted as a precautionary measure to prevent cows from worm infestation. Worms are hazardous to dairy cattle health such as suppression of nutrients, decreased milk yield, low weaning weight and decreased feed efficiency (Sharma, 2015). Cooperatives as a business organisation offers their members such essential services to cushion their animals from worm infestation. Dairy agripreneurs are, therefore, incentivised to sell to a market choice that cares for their production needs, which in this case were the cooperative market channels. This finding is similar to that of Twine et al. (2018), who found that dairy agripreneurs opted to sell milk to cooperative due to availability of animal health services such as deworming and vaccination services. Therefore, access to deworming support service increases the likelihood of dairy agripreneurs selling milk to dairy cooperatives.

Dairy agripreneurs who received vaccination service for their cattle were more likely to sell to retailers relative to cooperatives, by about 7.7 per cent (Table 4 ). This is probably because agripreneurs who vaccinated their cattle, were able to increase their milk yield due to increased immunity and reduced spread of disease among cattle. Many 
agripreneurs face the challenge of animal diseases and pests, which acts as stumbling blocks for increasing milk productivity in cattle in Kenya (Ngeno, 2018). Unfortunately, most of the agripreneurs in the study area had limited access to vaccination services, possibly due to poor infrastructure such as roads to reach remote villages, high cost of vaccination and poor access to good quality vaccines (Wane et al., 2019). In fact, dairy agripreneurs who invested in vaccination services, often sought for markets that offered quick payment and better prices in order to recover their extra investment cost; hence the choice of retailers. This was not helped by the fact that most cooperatives took long to effect payments for agripreneurs' milk, and mostly at lower than the prevailing open market price. Thus, the cooperative markets need to redesign their business model to ensure that their members receive better prices and prompt payments.

Access to supply of feeds also had a positive effect on the dairy agripreneurs' decision to choose middlemen/women and retailers as milk-marketing outlets in comparison to cooperative (Table 4). An increase in supply of feeds increased the likelihood of dairy agripreneurs selling milk to middlemen/women and to retailers by about 22.9 and $4.8 \%$, respectively. The biggest challenge that most agripreneurs faced was cost of production, particularly in terms of feed supply. Some agripreneurs joined cooperatives to protect themselves from this challenge, despite the presence of other markets that offered better milk prices. It is likely that if agripreneurs were able to easily access high supply of feeds, they would likely not choose cooperative as a market channel. This is because most dairy cooperative take time before they pay their members, yet majority of agripreneurs in Kenya depend on the farms as source of daily livelihood. Hence, the choice middlemen/women and retailers who offer quick payment. Kumar et al. (2019), found that dairy agripreneurs who had access to feeds for their animals preferred selling directly to consumer households since this market channel fetched higher prices, than selling through cooperatives.

\section{CONCLUSION}

The findings from this study suggest that the likelihood of selling to cooperative market channel is positively and significantly influenced by provision of business plan training, group marketing, pregnancy diagnosis and deworming support services. On the other hand, access to vaccination services and supply of feeds had negative and significant effects on the choice of cooperative market channel. Taken together, these results can inform the design and targeting of policies that aim at fostering utilisation of cooperative as a marketing channel for smallholder dairy agripreneurs. Strong linkages among the agribusiness support service providers and the dairy cooperatives is warranted to ensure dairy agripreneurs receive good quality, timely and consistent agribusiness support services. In addition, dairy cooperatives should redesign their business model to ensure members not only receive agribusiness support services, but also get better prices and prompt payment. This will enhance consistent supply of milk to cooperatives by smallholder dairy agripreneurs.

\section{ACKNOWLEDGEMENT}

This paper is part of $\mathrm{PhD}$ research work for the corresponding author. The study was funded by The Centre of Excellence in Sustainable Agriculture and Agribusiness Management (CESAAM), Egerton University - World Bank Funded Project. The authors are grateful to the MasterCard Foundation and Regional Universities Forum for Capacity Building in Agriculture (RUFORUM) for funding research and publication cost through the Transforming African Agricultural Universities to meaningfully contribute to 
Africa's growth and development (TAGDev) Program.

\section{REFERENCES}

Bardhan, D., Kumar, S. and Singh, R.K. 2015. Delivery of animal healthcare services in Uttar Pradesh: Present status, challenges and opportunities. Agricultural Economics Research Review 28(4):127-136. doi: 10.5958/0974-0279.2015.00028.2

Burke, W., Myers, M. and Jayne, T. 2015. A triple-hurdle model of production and market participation in Kenya's dairy market. American Journal of Agricultural Economics 97(4):1227-1246. doi: 10.1093/ ajae/aav009

Chagwiza, C., Muradian, R. and Ruben, R. 2016. Cooperative membership and dairy performance among smallholders in Ethiopia. Food Policy 59(1):165-173. doi.org/10.1016/j.foodpol.2016.01.008 0306-9192

Cochran, W.G. 1963. Sampling Techniques, 2nd Ed., New York: John Wiley and Sons, Inc.

FAOSTAT. 2018. Online database on Kenya dairy industry. Available at http://faostat. fao.org23/4/2019

Kilelu, C., Koge, J., Kabuga, C. and Van der Lee, J. 2018. Performance of emerging dairy services agri-enterprises: A case study of youth-led service provider enterprises (SPE). Wageningen Livestock Research. doi: 10.18174/446466

Kumar, A., Mishra, A. K., Saroj, S. and Joshi, P. K. 2019. Impact of traditional versus modern dairy value chains on food security: Evidence from India's dairy sector. Food Policy. doi: 10.1016/j.foodpolicy. 2019. 01.010

Kumar, A., Saroj, S., Joshi, P.K. and Takeshima, H. 2018. Does cooperative membership improve household welfare? Evidence from a panel data analysis of smallholder dairy farmers in Bihar, India.
Food Policy 75(1):24-36. doi: 10.1016/ j.foodpol.2018.01.005

Lutz, C. and Tadesse, G. 2017. African farmers' market organizations and global value chains: Competitiveness versus inclusiveness. Review of Social Economy 75(3):318-338. doi.org/10.1080/00346 764.2017.1300317

Murang'a County Integrated Development Plan. 2018. Strategic plan for 2018-2022. Retrieved from https://cog.go.ke

Mwambi, M., Bijman, J. and Mshenga, P. 2018. Which type of producer organization is (more) inclusive? Dynamics of farmers' membership and participation in the decision making process. Annals of Public and Cooperative Economics 1(2):1-24. doi.org/10.1111/apce.12269

Ngeno, V. 2018. Impact of dairy hubs on smallholder welfare: Empirical evidence from Kenya. Journal of Agricultural and Food Economics 9(6):2193-7532. doi.org/ 10.1186/s40100-018-0107-3

Oleksiy, O., Hayes, L., Krueger, N.F. and Madill, C. 2013. Planning to grow? Exploring the effect of business planning on the growth of small and medium enterprises (SMEs). Entrepreneurial Practice Review 2(4): 36-56. SSRN: https:/ /ssrn.com/abstract=2392921

Oloo, B.O. 2016. Lessons in sustainable dairy farming to Kenyan dairy sector from the Dutch Dairy Sector. Journal of Advances in Dairy Research 4(1):162-172. doi: 10.4172/2329-888X.1000162

Omondi, I., Zander, K., Bauer, S. and Baltenweck, I. 2017. Understanding farmers' preferences for artificial insemination services provided through dairy hubs. Animal 4(1):677-686. doi: 10.1017/S1751731116002354

Royer, A., Bijman, J. and Bitzer, V. 2016. Linking smallholder farmers to high quality food chains: Appraising institutional arrangements. In: Quality and Innovation in Food Chains: Lessons and Insights from 
Africa; Wageningen Academic Publishers: Wageningen, The Netherlands. pp. 359381. doi: 10.3920/978-90-8686-825-4

Sharma, V.P. 2015. Determinants of small milk producers' participation in organized dairy value chains: Evidence from India. Agricultural Economics Research Review 28(2):247-261. doi: 10.5958/0974-0279. 2016.00004 .5

Singh, D. 2018. Determinants of dairy farmers' choice of marketing channels in Bihar, India. Agricultural Economics Research Review 31(1):149-155. doi: 10. 22004/ag.econ.274836

Twine, E., Rao, E., Baltenweck, I. and Omore, A. 2018. Are technology adoption and collective action important in accessing credit? Evidence from milk producers in Tanzania. European Journal of Development Research 31(1):388-412. doi.org/10.1057/s41287-018-0158-Z

Van der Lee, J., Klerkx, L., Bebe, B., Mengistu, A. and Oosting, S. 2018. Intensification and upgrading dynamics in emerging dairy clusters in the east African highlands. Sustainability 10(11):4324. doi.org/ 10.3390/su10114324.

Wane, A., Dione, M.M., Wieland, B., Rich, K.M., Yena, A.S. and Fall, A. 2019. Willingness to vaccinate (WTV) and Willingness to pay (WTP) for vaccination against peste des petits ruminants (PPR) in Mali. Frontiers in Veterinary Science 6(1):1-12. doi: 10.3389/fvets.2019. 00488 Wongtschowski, M., Belt, J., Heemskerk, W. and Kahan, D. 2013. The business of agricultural business services: Working with smallholders in Africa. Royal Tropical Institute, Amsterdam; Food and Agriculture Organization of the United Nations, Rome, Italy; and Agri-ProFocus, Arnhem.

Wortmann-Kolund•ija, E. 2019. Empowering smallholder farmers through farmer organizations: Insights from Kenya and Burkina Faso. SSRN Electronic Journal 182. doi: 10.2139/ssrn.3498199 